\title{
Salt for the earthen oven revisited
}

\author{
Author: \\ John J. Pilch ${ }^{1,2}$ \\ Affiliations: \\ ${ }^{1}$ Department of Theology, \\ Georgetown University, \\ Washington DC, United \\ States \\ ${ }^{2}$ Department of New \\ Testament Studies, \\ University of Pretoria, \\ South Africa \\ Note: \\ Prof. Dr John J. Pilch is \\ participating as research \\ associate in the project \\ 'Biblical Theology and \\ Hermeneutics', directed \\ by Prof. Dr Andries G. van \\ Aarde, honorary professor \\ in the Faculty of Theology, \\ University of Pretoria, \\ South Africa.
}

Correspondence to:

John Pilch

email:

pilchj@georgetown.edu

Postal address:

1319 Black Friars,

Catonsville, MD 21228

2710, United States

Dates:

Received: 08 Apr. 2010

Accepted: 14 May 2010

Published: 07 June 2011

How to cite this article:

Pilch, J.J., 2011, 'Salt for the earthen oven revisited' HTS Teologiese Studies/ Theological Studies 67(1), Art. \#826, 5 pages. DOI: $10.4102 /$ hts.v67i1.826

(C) 2011. The Authors Licensee: OpenJournals Publishing. This work is licensed under the Creative Commons Attribution License.
The symbolic interpretation of the salt sayings in the New Testament (Mt 5:13; Mk 9:42-50; Lk $12: 49-53 ; 14: 34-35)$ is best based on the long-standing cultural practice of using salt as a catalytic agent to burn dung, the common fuel for the typical earthen oven used by peasants even to this day. Seasoning and preservation are culturally inappropriate.

\section{Introduction}

Basing himself on the work done by De Langhe (1954:165-167), Malina (2001:237) argued as early as in 1981 that, in the ancient world, salt was a catalytic agent used in the typical earthen oven by peasants to facilitate the burning of dung, the common fuel. He repeated that information in a commentary first published in 1992 (Malina \& Rohrbaugh 2003:41). Pilch included this information in his Cultural dictionary of the Bible (Pilch 1999:4-5). The value of this insight was its ability to shed significant cultural light on the salt sayings in the New Testament (Mt 5:13; Mk 9:42-50; Lk 12:49-53; 14:34-35). A computer search for 'salt' and 'oven' turns up a number of contemporary websites devoted to the investigation of biblical topics that report and discuss this interpretation favourably.

Since the first appearance of this information, however, scientifically minded Western readers have challenged the interpretation, because, according to their scientific understanding, a catalyst never loses its ability as a catalyst. None of these objectors appears to have travelled to the Middle East to witness this practice in an earthen oven, or have attempted an experiment to prove or disprove the practice. In this article I would like to revisit the interpretation proposed by Malina (2001), Malina and Rohrbaugh (2003) and myself (Pilch 1999) with a view to expanding what we have previously published.

\section{Symbolism of salt}

Latham (1982) published an extensive review of the symbolic significance of salt in the Scriptures and the Liturgy. In the first part of his book, he researched salt in the Old Testament (OT) as used in sacrifice, as related to the covenant, as associated with meals and permanence and also as a curse. In general, he concluded that the OT usage of salt symbolised a close relationship with Yahweh, commonly expressed as the 'covenant of salt'.

Turning then to the Liturgy and the Fathers of the Church in the second part of his book, he identified and summarised seven main themes familiar to the early Church: preservation, exorcism, fragrance, salt of wisdom (associated with taste), salt associated with the word, salt as food and salt as promoting health. He admitted that these symbolic meanings often lacked logical development. To his great surprise they even lacked references to the important OT concept of 'salt of the Covenant'! As for the Liturgy, salt 'apparently developed without any connections, explicit or implied to a specific symbolism' (Latham 1982:183). Nevertheless, he insisted that, although salt as a symbol of table fellowship and of sealing a covenant was never explicitly or implicitly developed in the Liturgy, these notions 'must have made salt an irresistible attractive symbol' (Latham 1982:185).

In the final section of his book, Latham applied these insights to the New Testament salt passages mentioned above (Latham 1982:189-242). Salt, he observed, can have many symbolic interpretations (Latham 1982:191). He pointed this out as he interpreted each of the passages variously referring to salt as seasoning and as preservative and embellished each interpretation with theological insight drawn from the first two sections of his book. He agreed with Jeremias (1963:169-170) in rejecting De Langhe's interpretation of salt as a catalyst to activate the fire in the earthen oven (Latham 1982:207).

\section{Salt as seasoning and preservative}

Salt is commonly used as seasoning in the West and everyone knows that salt induces thirst. In ancient Palestine there were only two seasons (wet during October-April period and dry 
during May-September period). Water was scarce and precious. If water was too scarce for peasants to observe all the requisite purity ablutions (Mk 7:1-5), why would one intentionally induce thirst by using salt as a seasoning (Job 6:6 notwithstanding)? Common seasonings at present include cumin, zatar, dill, capers, mint and many more (Borowski 2003:72). As for salt as a preservative, Borowski notes that meat was very rare in the peasant diet and it therefore was not part of daily fare (Borowski 2003:67-70). Biblical references to the preparation of meals indicate immediate consumption (see Lk 15:23, where the entire village feasts on the fatted calf). Moreover, whilst extra-biblical evidence (e.g. ethnography or ancient literature) indicates that meat was smoked, dried or salted for longer storage, there is no evidence at all in the Bible for such preservation.

\section{Salt in the earthen oven}

Danker (2002) defines the Greek word $(g \bar{e})$, translated as 'earth' in Matthew 5:13 and Luke 12:49, as 'the inhabitants of the earth, people, humanity, an associative sense'. However, the Greek quite likely renders the Hebrew eres which means earth in most cases, but in two places in the Hebrew Bible means earthen oven. In the first place we read, 'The promises of the Lord are promises that are pure, silver refined in a furnace on the ground, silver refined seven times' (Ps 12:6). The phrase 'furnace on the ground' describes an earthen oven used in the refining process. In the second place it says, 'As for the earth, out of it comes bread, but underneath it is turned up as by fire' (Job 28:5). Grain comes out of the earth, but bread comes out of the earthen oven. The preceding context (Job 28:1-4, which speaks of refining silver, gold and copper) makes the interpretation of earth as earthen oven very plausible. Consequently, Matthew 5:13 is preferably translated: 'you are the salt of the earthen oven', whilst Luke 12:49 is preferably translated as 'I came to light the oven'. The Palestinian Arabic word for kiln oven, ars a, confirms this understanding (De Langhe 1954:166). From such translations, a reader can then draw out the intended symbolism, as will be demonstrated below.

\section{Salt as catalyst}

De Langhe's (1954:165-167) hypothesis about salt as a catalyst still appears to be the most culturally plausible basis for determining the symbolism of the salt sayings in the New Testament. Scholten (1935:114-117) seems to have been the first to publish this insight with illustrations. Palestinians from the 1st century placed flat plates of salt on the bottom of their earthen ovens to activate the fire. Salt had a catalytic-like effect on the fuel (dung), causing it to burn. After some years, the salt plates in the earthen oven underwent a chemical reaction due to the heat. The result was that the salt no longer facilitated the fire, but rather impeded and stifled the burning of the dung. It is in this sense that salt used for this purpose lost its saltness (see Mk 9:50 'analos, which suggests how to understand Mt 5:13 and Lk 14 'alas mōranthē), that is, its ability to facilitate a fire.

\section{Dung as the fuel}

Given the dearth of trees in ancient Palestine, it is not surprising that wood was not the fuel used in the earthen oven. Dung, which was plentiful, was the commonly used fuel. Disappointed with Jeroboam, God condemned him through Ahijah:

Therefore behold, I will bring evil upon the house of Jeroboam, and will cut off from Jeroboam every male, both bond and free in Israel, and will utterly consume the house of Jeroboam, as a man burns up dung until it is all gone.

(1 Ki 14:10)

An old tradition says the Bible is the best commentary on the Bible.

Human faeces are not appropriate fuel. Instructing the prophet Ezekiel on how to present the divine message about the forthcoming disaster in prophetic symbolic action, God tells him to bake a barley cake on human excrement in the sight of all the people. Of course, this was intended to show how desperate the coming cataclysm would be. When Ezekiel demurs because human excrement is repulsive, God allows him to substitute cow dung (Ezk 4:12, 15). It is important to note that human excrement is not unclean, as some commentators claim (citing Dt 23:12-14). It is simply repulsive, inappropriate, 'indecent' (RSV), but clean from a purity point of view (Malina 1988:22-25). Greenberg (1983:107) recounts a report from 1841 about travellers to the Middle East who ate bread baked in the embers of a fire of camel and cow dung.

Goat and sheep dung are also not useful, because these are too dry. The ideal is donkey, camel or cow dung mixed with chaff (see Is 25:10). Archaeological excavations in Iran discovered that peasant housing had places to keep animals (compare Lk 2:7 for Palestine) and a storage room for the fuel, that is, the dung patties (Borowski 2003:73; Holladay 2009:66-67;). Approximately 2000 patties would be required for a year's supply of fuel. The dung was collected and shaped by the women and the girls in the warm months. It was always women's work. Sometimes the dung would be laid end to end to dry and sometimes it was dried on the roofs.

\section{Interpreting the New Testament salt passages}

Latham is correct is seeking to discover the symbolism behind the New Testament salt passages. However, in rejecting the culturally most plausible basis for the symbolism, namely salt as the catalyst for fire in the earthen oven, he is repeatedly forced to admit that many of the - even contradictory symbolic interpretations he discovered are possible. For example, regarding Mark 9:49 he says, 'Mark's logion is unusually difficult to interpret not because it lacks sense, but rather because it is too rich in symbolism to settle on any one meaning' (Latham 1982:239). Would Jesus have left his message open to multiple and equally valid interpretations? We revisit the salt passages with De Langhe's insights and 
show that the context of each does seem to support symbolic interpretation based on his insight, an interpretation certainly intended by the Evangelists and, if traceable to Jesus, most likely by him too.

\section{Matthew 5:13}

Latham claims that this verse fits poorly with its context. It has 'no apparent connection with what went before or with the comparison of the Two Laws that follows' (Latham 1982:203). He continues: 'There is, of course, no way of knowing exactly what Matthew had in mind when he had Jesus address the disciples as the "salt of the earth"' (Latham 1982:206). He concludes that the Christian community inherited the honour of Israel (its function and titles) and this is what the disciples should preserve. Because Jesus came to fulfil the Law rather than to abolish it, the disciples should love one another (Latham 1982:211).

Translating Matthew's text with De Langhe's (1954) insight suggests that it is quite possible to know what Matthew might have had in mind:

You are the salt of the earthen-oven; but if salt has lost its saltness (i.e., its ability to facilitate the burning of dung), how shall its saltness (that ability) be restored? It is no longer good for anything except to be thrown out and trodden under foot by men.

(De Langhe 1954:166)

At the level of reality, that is, earthen ovens, dung fuel and salt, the catalyst no longer serves its purpose and must be replaced. It is no longer good for anything except to be thrown out where people will step on it.

In the Sermon on the Mount (Mt 5-7), Jesus begins with the makarisms, which redefine the core cultural value: honour (Hanson 1996). There are over 80 makarisms in the Bible, but Jesus' stand in contrast to them. 'Truly honorable are the poor in spirit, for theirs is the kingdom of heaven, etc.' (Mt 5:3ff). Such freely chosen behaviour is certain to stir opposition. Indeed, Jesus concludes by observing that, by implementing the values proposed in his makarisms, his disciples are likely to be persecuted for righteousness' sake, 'on my account', falsely. When that happens, he exhorts: 'Rejoice and be glad, for your reward is great in heaven, for so men persecuted the prophets who were before you' (Mt 5:12).

Then follows the salt logion. Recall that this culture is agonistic, that is, prone to conflict. It loves arguments, admires insults and honours those who are adept at these indications of mastery of language. Living according to the makarisms (the 'gospel') in this culture is like being catalytic. If, however, believers have lost this ability to stir conflict, this quality, by electing not to live according to the makarisms, they are good for nothing but to be thrown out! The next images (light of the world, city set on a mountain [not hill! same word as in Mt 5:1], lamp on a stand in the house, your light, Mt 5:14-16) are a natural segue from the image of fire expected in the earthen oven. These verses are structured like this: $a$ - light: $b$ - city: $b^{\prime}-$ lamp: $a^{\prime}-$ light. The relationship of light in $\mathrm{a}+\mathrm{a}^{\prime}$ is clear, but city and lamp in $\mathrm{b}$ and $\mathrm{b}^{\prime}$ ? Von Rad's (1966:232-242) analysis explains it clearly. He notes that the city is the eschatological city of God (Is 2:2-4; Mi 4:1$3)$. It is to be revealed at the end time by God and is a large, walled city above all human habitations, with total security. It has its own light supply, therefore it is always bathed in light. The entire world can see it. (Some archaeologists think that the view of Sepphoris from Nazareth might have been the inspiration for this image.) The fact that this mythological mountain-city has its own light supply explains why it is associated with 'lamp'. There is a pun between the Hebrew/ Aramaic 'or (light) and 'ir. The conclusion then is, 'Let your light so shine before men, that they may see your good works and give glory to your Father who is in heaven' (Mt 5:16). In other words, be salt to ignite and sustain the fire and produce the necessary light. This light symbolises the righteousness of the disciples (Mt 6:19-7: 29), which must surpass that of the scribes (Mt 5:20-48) and Pharisees (Mt 6:1-18), as the rest of the Sermon explains.

\section{Luke 14:34-35}

After presenting his interpretation of the logion in Luke, Latham (1982) concludes:

If Luke wished to indicate the practical utility of salt - which would have been nullified once salt lost its savor - he most certainly would have referred to seasoning and conservation and not to some obscure use for the land or dunghill.

(Latham 1982:271)

Luke's point is that discipleship is good, just as is salt. But if a disciple becomes foolish (Latham's symbolic interpretation of salt losing its savour), the consequences are dramatic. In effect the disciples are being told: Think twice! Don't act like a fool. Interestingly, Latham reaches a conclusion similar to ours, but in a roundabout (tortuous?) way. However, we already mentioned why seasoning and conservation are not plausible interpretations in the biblical context.

Once again, following De Langhe's (1954) insight, this is how Luke's logion can be understood:

Salt (the catalyst) is good; but if salt has lost its saltness (its ability to serve as a catalyst in the earthen-oven), how shall its saltness be restored? It is fit neither for the earthen-oven (land) nor for the dunghill, that is, the fuel supply; men throw it away. He who has ears to hear, let him hear.

(Lk 14:34-35; De Langhe 1954:166)

The broader context of the logion is discipleship. The parable in Luke 14:1-24 tells how some prefer possessions (field and oxen) and family ties (married a wife) to responding to an invitation. Jesus follows the parable with an invitation to each of his disciples to cut family ties and bear his or her own cross daily and follow him (Lk 14:25-27). Cutting family ties is cultural suicide, but such an action represents the height of agonism. It destroys the family and initiates severe family discord and feud. It should never be done (Lk 15:11-32). To be a disciple of Jesus requires that one continue to embrace the culture's preference for conflict (salt is good), but in a very unexpected and unsettling way. The two parables (Lk 14:2832: Tower builder, King going to war) advise taking one's 
choices seriously, then being prepared for persevering to the end. An inclusio (Lk 14:26 and 33 - breaking family ties = renouncing all one has) binds into a unit Jesus' advice rooted in the agonistic character of this culture. The Evangelist then appends the salt logion (Lk 14:34-35) to emphasise this point and concludes with 'He who has ears to hear, let him hear'.

\section{Luke 12:49}

This saying is relatively easy to interpret in its immediate context. Following De Langhe again, we would interpret it as follows: 'I have come to light the oven,' said Jesus, 'and I wish it were already aflame' (Lk 12:49; De Langhe 1954:166). Jesus now wishes that the apostles and disciples would make the flame continue to burn. Verses 51-53 report the effect that Jesus and his message had upon families. Culturally speaking, all family members ought to do what the Patriarch decides (see Jos 24:15 - 'as for me and my house,' says Joshua, 'we will serve the LORD', which was surely proclaimed without calling a family conference; see also Ac 16:31-33). But Jesus and his message stimulate the cultural agonism to such a point that it even disrupts family harmony. Instead of obeying the Patriarch, family members with different views of Jesus and his message turn on each other. It is interesting to note how Luke's Jesus moves from the 'realistic' use of the word 'earthen-oven' (v. 49) to the symbolic use of the word in verse 51. The final exhortation to 'judge for yourselves what is right' (v. 57) is similar to the challenge posed by the two parables discussed above. Do not be afraid to make and persevere in decisions regarding discipleship that may cause conflict and dissension.

\section{Mark 9:49}

Admittedly this is a very difficult saying to interpret. Latham reports that Vincent Taylor lists 14 different interpretations. As is his custom in this book, Latham remarks: 'Any attempt to tie down a symbol to one precise meaning is to destroy it. It automatically becomes a sign' (Latham 1982:231-233). His reflection concludes: 'As can be seen, there is no end to possible interpretations of this logion, rich as it is in symbolisms' (Latham 1982:238). In general, however, he claims the interpretation should be that 'everyone subjected to fire will either emerge whole and purified or perish in the consuming fire that is never quenched' (Latham 1982:240).

Following the line of De Langhe's (1954:167) argument, it is perhaps preferable to understand the saying as: 'Everyone should be and behave as salt for a fire'. The section begins in Mark 9:30, with Jesus' second prediction of his forthcoming death and resurrection. It is followed by the report that, along the way, the agnostic disciples, true to cultural form, were arguing with each other about who amongst them was the greatest. The section ends in verse 50, with Jesus' exhortation that they retain their agnostic cultural heritage ('have salt in yourselves') and remain at peace with one another.

In response to their argument about who was greatest amongst them, Jesus urges them to rather be like children, the 'throw-aways' in this society (Mk 9:35-37). It was an insulting suggestion, but par for the course for Jesus, the agonistic master of insult as Matthew in particular highlights. (Review his use of the word hypocrites = actors, as Jesus' favourite and repeated insult directed exclusively against his favourite antagonists, the Pharisees.) The disciples then reveal yet another instance of their agonism when they forbid a competitor from doing the same good thing they do, because he was not one of their in-group. Jesus in reply attempts to moderate their agonistic response to the man's good deeds (Mk 9:38-41).

Returning to the topic of 'the little ones', Jesus then presents three scenarios, each of which contains the word 'fire' or implies it (Mk 9:42-48). It is this triple allusion to fire that prompts the Evangelist to segue to the statement as interpreted by De Langhe (1954:n.p.), namely 'for everyone should be and behave like salt for the fire'. Indeed, in this agnostic culture, everyone is conflict prone (salt for the fire). In other words, Jesus observes: You have just illustrated my point about salt for the fire with your argument about the greatest among you, and your dismissal of a person who believes in me and does what you and I do. Salt the catalytic agent is good. But if it can no longer perform its proper function but rather goes out of control, starting fires where none are needed, it is as useless as if it could no longer start or sustain any fire. So remain salty or catalytic and also remain at peace with one another. Hold fast to your agonistic cultural values but don't allow yourselves to become vanquished by them.

\section{Conclusion}

Interpreters like Latham err not because they neglect to seek the basis in reality behind the symbolism that they attribute to the New Testament verses about salt, but rather because they fail to seek the most culturally plausible reality behind that symbolism. Latham appears to have either totally rejected or minimised a cultural basis for the symbolism (e.g. salt, dung, earthen oven) in favour of a theological basis. I have argued that applying De Langhe's insights to these New Testament verses, Jesus and/or his interpreters, the Evangelists, seemed to accept the cultural meaning of salt as catalyst, dung as fuel and their respective role in earthen ovens as the basis for a symbolic meaning in order to promote and elicit appropriate cultural behaviour amongst disciples, behaviour, of course, appropriate to that culture.

\section{References}

Borowski, O., 2003, Daily life in biblical times, Society of Biblical Literature, Atlanta.

Danker, F.W. (ed.), 2000, A Greek-English Lexicon of the New Testament and Other Early Christian Literature, by Walter Bauer, 3rd rev. edn., University Press, Chicago.

De Langhe, R., 1954, 'Judaïsme ou Hellénisme en rapport avec le Nouveau Testament [Judaism and Hellenism with reference to the New Testament],' in L. Cerfaux et al. (eds.), pp. 154-183, L'Attente du Messie, Recherches Bibliques, Desclée de Brouwer, Paris.

Greenberg, M., 1983, Ezekiel, 1-20, The Anchor Bible, 22, Doubleday, New York.

Hanson, K.C., 1996, 'How honorable! How shameful! A cultural analysis of Matthew's makarisms and reproaches', Semeia 68, 83-114.

Holladay, J.S. Jr., 2009, “Home Economics 1407" and the Israelite family and their neighbors: An anthropological/archaeological exploration', in P. Dutcher-Walls (ed.), The family in life and in death: The family in ancient Israel: Sociological and archaeological perspectives, pp. 61-88, Clark, London/New York. 
Jeremias, J., 1963, The parables of Jesus, transl. S.H. Hooke, Charles Scribner's Sons, New York.

Latham, J.E., 1982, Religious symbolism of salt, Théologie Historique, 64, Beauchesne, Paris.

Malina, B.J., 1988, 'A conflict approach to Mark 7', Foundations and Facets Forum 4(3), 3-30.

Malina, B.J., 2001, The new testament world: Insights from cultural anthropology, 3rd edn., Westminster John Knox, Louisville.
Malina, B.J. \& Rohrbaugh, R.L., 2003, Social science commentary on the synoptic Gospels, 2nd edn., Fortress, Minneapolis.

Pilch, J.J., 1999, The cultural dictionary of the Bible, The Liturgical Press, Collegeville.

Scholten, F., 1931, Palestina: Bijbel, Talmud, Koran: Een volledige illustratie van alle teksten door middel van eigen artistieke foto's uit het heden en verlede van het Heilig Land, Sijthoff, Leiden.

Von Rad, G., 1966, The problem of the Hexateuch and other essays, McGraw-Hill, New 